\title{
Model for Goverment Procurement of Good / Services Training
}

\author{
Hery Suroso ${ }^{1}$, Joko Widodo ${ }^{2}$, Joko Sutarto ${ }^{3}$, Suwito Eko Pramono ${ }^{4}$ \\ \{herysuroso12@mail.unnes.ac.id $\left.{ }^{1}\right\}$ \\ Department of Civil Engineering, Faculty of Engineering, Universitas Negeri \\ Semarang ${ }^{1}$
}

\begin{abstract}
This study aims to: (1) analyze the training model for procurement of goods and services that have been carried out so far, (2) return the training model for procurement of goods and services (3) produce a model that suits your needs. The subjects of this research are training participants of goods and services registered with the Government's Goods and Services Procurement Policy Institute who have graduated. The research location is taken from data in LKPP. The sampling technique uses stratified random sampling, so how to take a sample is divided by age level. Data analysis techniques in this study used research and development (research and development). The results show that of the various training models available, the most suitable and appropriate use the problem-based training model.
\end{abstract}

Keywords: Development, Education, Goods and Services

\section{Introduction}

Training is part of investing in human resources (human investment) to improve job abilities and skills, and thereby improve employee performance. Training is usually carried out with a curriculum that is tailored to the needs of the position, given in a relatively short time, to equip a person with job skills (Simanjuntak, 2005).

The implementation of good governance is highly believed to have made a strategic contribution in improving the people's welfare because the implementation of good governance is expected to be able to avoid deviations which are the beginning of acts of corruption and bribery (Kristiadi, 2006).

The procurement of goods / services at government institutions are the main tasks of the government institutions which are not to produce goods / services aimed at profit-oriented, but rather provide services to the public. Therefore, the government needs goods / services in order to improve public services based on logical and systematic thinking, following principles and ethics and based on applicable procurement methods and processes. Training and certification examinations as an effort to improve the competence provided to training participants and the 
certification exam for the procurement of goods / services aims to increase the competence and professionalism of participants and their function in goods / services procurement services.

Training planning has not provided maximum results. From the available data, there are only 29,000 of the 102.000 training participants who have successfully passed and are entitled to obtain certificates, or only around $31 \%$. After the participants who passed the training has become procurement officials, more than $50 \%$ of them have low competence, graduates have difficulty in dealing with the problem of the procurement of goods / services in their respective institutions. It is suspected that this problem is caused by poor planning for procurement of goods / services, ranging from inaccuracies in determining the learning method which focuses more on lectures, the curriculum that is rarely reviewed, exam questions in the form of case studies that are given a smaller percentage, material memorizing training and textbooks have not led to real - life cases and practices carried out in the field, LKPP has not made a graduation test specifications, the validity and reliability of exam questions have never been carried out, low instructor pedagogical competence, input of training participants who are not selected from the agency of origin. Due to poor planning, the implementation and evaluation stages of the procurement of goods / services training are also not good.

The learning methods have been lectures, brainstorming, question and answer, exercises, and discussions. These methods are not effective for the purposes of training in the procurement of goods / services because: (1) they cannot provide practical experience in the process of procuring goods / services; (2) unable to provide examples of practical problems encountered in the process of procuring goods / services; (3) does not provide examples of practical solutions in the process of procuring goods / services; and (4) does not provide examples of regulatory developments, prices for goods / services in the market, and specifications for prices of goods / services in the market. The four reasons were explained by several representatives from LKPP and the training participants. LKPP explained that the learning methods that have been used need to be reviewed because: (1) examples of cases and their solutions are considered impractical and textual; (2) participants do not feel like they are working in the goods / services procurement department; and (3) they have difficulty understanding the regulations and procedures for the procurement of goods / services.

Theoretically, the lecture method has the weakness that what participants can master because of the lecture is limited to what the instructor can master. This is indeed the most dominant weakness, because what the teacher gives is what he / she is good at, so that what the trainees master depends on what the instructor has mastered. The question-and-answer method has a weakness because it is not easy to make questions that are appropriate to the thinking level and easily understood by the participants. In the brainstorming method, participants are more dominated by understanding the material and being active, while training participants who do not understand the material less and are less active have difficulty following the training material.

Implementation of problem-solving methods requires good planning. Planning must understand well that compiling a plan means trying to systematically decide what to do by the organization in the future to realize certain future conditions that are expected to benefit the organization. Therefore, all plans that are drawn up must continuously pay attention to 
efficiency factors, which means that with a variety of resources and limited resources optimal results are obtained.

The Planning of the Training Model in Procurement of Goods / Services Government is based on the pattern of planning of the training related to designing the training can be a solution to the problems of training planning procurement of goods / services Government .

According to Mujiman (2011 : 19), training planning is one of the keys to overcoming training problems. The planning of the training can lead to the process of achieving that goal. Planning a good training will manage the training program systematically through these following: identification of training needs, design planning, training methods, develop training materials, training delivery, training evaluation and determination of follow-up training.

A study conducted by Arthur \& Bennet (2016) states that gaps in the training effectiveness literature by conducting a meta-analysis of the relationship between defined designs and evaluation features and training effectiveness in organizations. Empirical studies that involve evaluating training programs or measuring some aspects of training effectiveness. The training evaluation criteria obtained additional results indicating that the comparison of the learning criterion with the next criterion, which is the behavior and outcome showed a significant decrease in the effect of learning to this criterion. Then, the researcher found in the metaanalysis that the strong effect of the lectures, as opposed to its poor public image, appeared to be quite effective in practicing certain types of skills and assignments. The effectiveness of multiple training methods for the same content and a single training method across multiple skills and tasks is guaranteed.

Armstrong (2009: 67) argues training is a systematic behavior modification through learning, which occurs because of education, the development of learning and experience are planned. Noe (2010: 351) argues training is an effort planned by an educational institution to facilitate learning about work-related competencies, which include knowledge, skills, attitudes and behavior.

Beets \& Goodman (2018) explain that certain aspect of the results of an executive coach training program, and the extent to which the knowledge, skills and attitudes acquired during the program are applied in a practical setting. The method widely used is SCM which follows a mixed methods approach. Six trainers successfully applied the proximal results of the training. The trainers saw the results and value of this training. In addition, identifying the aspects that help and obstruct the result during the implementation of knowledge, skills, and attitudes can lead to suggestions to improve the training. The six successful cases show that these successes help clients become self-correcting, self-producing, and have excellent longterm performance. The results show that the SCM proves to be a useful and practical evaluation tool for conducting evaluation of this training which produces results to motivate future participants and is a practical way to evaluate the success of an intervention.

Gaengreco \& Carugati (2019) explain that the evaluation system which allows for the collection of information that is useful to trainees, trainers, and HR professionals as well as the conditions that can be taken to facilitate action in a changing environment. Based on those considerations, the researcher understands the different time frames for developing the 
evaluation process. Evaluating follow-up training uses a multi-level model to collect information which includes affective reactions to training, knowledge acquisition and retention, changes in job behavior, and improved organizational outcomes. In dealing with choices and understanding various options, training evaluation is used, and the results are compared with the evaluation method. The evaluation is based in part on Kirkpatrick's model. Kirkpatrick's model is based on the model used in this study, because the instrument allows the identification of indicators that can be quantified in the short term, but their use is limited to the first level. The evaluation at the fourth level is costly because it requires time and costs that cannot be accepted by the certification auditors of quality control and monitoring time. Therefore, the evaluation is limited to answering questionnaires on topics such as logistics, content, and worker satisfaction. The procedure is completed when collecting questionnaires and entering data into a correspondent database.

A model is defined as a pattern (example, reference, variety) of something to be created or produced (KBBI, 2015). Learning is an activity of educators in teaching students or placing students in learning conditions (Syahza \& Irianti, 2008). The learning model is a design of the learning model used by educators to assist learners to acquire information, ideas, skills, ways of thinking, and expressing their own ideas (Joyce et al., 2011).

The learning model serves as a guide for instructional design and educators in carrying out learning. Choosing a learning model is influenced by the characteristics of the instructional material, the teaching objectives, and the characteristics of the learners. Each learning model has stages (syntax) that learners can do with the guidance of educators (Komalasari, 2011).

Utomo (2016) shows that the factual models, the needs analysis on training was not performed. Therefore, the relevance is low, and the learning process be less attractive and meaningful. In addition, controls were also not carried out effectively so that they cannot assess the reaction and impact of the training.

This study employed research and development design. The development was carried out in three stages: (1) preliminary studies including literature studies, field studies and preparation of prototype products; (2) model development includes product preparation, product validation, product revision, limited trial, and trial result revision; (3) model testing includes product testing through experiments, final product preparation, and product socialization. Product socialization is not carried out with time considerations and the consideration that at the model development stage, a valid model has been produced (Borg and Gall, 2007 : 772) .

The output target is to produce a Good/service Procurement Training Model to increase the number of passing participants and effective instructor competencies that can be used in a wider audience. The data were analysed qualitatively and quantitatively on the implementation of the training model. Qualitative analysis was used to describe the results of preliminary study, quantitative analysis was used to the implementation and influence of the developed model. Quantitative analysis was used to analyse the difference (gain) of competency mastery according to its components before the implementation of the model (pretest), with mastery of competencies after the implementation of the model (post-test). Furthermore, the results of the pre-test and post-test were compared between the treatment group instructors and the control group instructors. Therefore, it will be able to determine the amount of net gain, gain is 
interpreted by the amount of increase in instructor competence which is more convincing as an effect of the implementation of the developed training model. The effect of implementation model of training to increase the competency is indicated by the comparison between gain score on the treatment group with that on the control group as net gain (Kirkpatrick, 2006).

Factual data collection was performed in all of Indonesia by LKPP and number of certificate holder skills up to the period of 2005 to 2018 consisting of 271.365 people. Methods / Techniques of the current training exists consisted of lecturing, brainstorming, discussion, buzz groups, exercises, and discussions. The current methods and techniques still did not make the goods / services training participants understand the material presented by the instructor. This can be seen in the passing rate on the goods / services procurement certification exam held by LKPP based on the age range.

The results of the planning analysis for the procurement of goods / services that are used as the basis for developing a training model. The development of the training model was conducted by using survey research with the observations of the learning process, interviews with goods / services procurement instructors, and distributing questionnaires to participants who take training and certification of goods / services procurement. Based on the results of the analysis of the survey research, it is recommended to develop a new training model that can overcome some of the problems above and a training model that is able to improve the competence of participants in solving problems related to the procurement in their respective institutions.

\section{The Results of Product Validation}

Validation of the developed products which include training mdoel, book models, and the learning administration was performed by asking for a expert judgment in the field of Goods / Services procurement. The results of the validation assessment are described in detail as follows.

\subsection{Results of Input from the Procurement of Goods / Services Experts from LKPP}

Table 1. Inputs of Experts and Practitioners of Training Management Model Design

\begin{tabular}{clcl}
\hline No. & Assessment Aspects & Information & \multicolumn{1}{c}{ Input } \\
\hline 1 & Model Clarity & Good & Adjust training needs \\
2 & Content accuracy & Good & It needs to be adapted to the conditions of \\
& & Enough & the participants \\
3 & Relevance & Good & We recommend that you add the outcome of \\
4 & Systematics Model & Good & the training model \\
\hline 5 & Model outcome & & \\
\hline
\end{tabular}




\subsection{The Results of Expert Validation}

\subsubsection{The Results of Validation of Model Book Contents}

The results of the recapitulation of the model book content validation can be seen in table 2 as follows.

Table 2. Recapitulation results of the validation of model books

\begin{tabular}{clccc}
\hline $\begin{array}{c}\text { Table } \mathbf{1} \text { Recapitulation } \\
\text { Results of the } \\
\begin{array}{c}\text { Validation of Model } \\
\text { Book ContentsNo. }\end{array}\end{array}$ & \multicolumn{1}{c}{ Indicator } & $\begin{array}{c}\text { Percentage of } \\
\text { validity } \\
(\boldsymbol{\%})\end{array}$ & Information & Conclusion \\
\hline 1 & $\begin{array}{l}\text { Material Planning } \\
\text { Material Delivery } \\
\text { Planning } \\
\text { The Content of the } \\
\text { training the Material } \\
\text { Material Purpose }\end{array}$ & 86.5 & Very Valid & Very feasible \\
3 & Material Evaluation & 77 & Valid & feasible \\
4 & Conclusion & 82.5 & Very Valid & Very feasible \\
5 & & & Valid & Well feasible \\
& & & Very Valid & Very feasible \\
\hline
\end{tabular}

Before being used for field trials, the contents of the model book were revised according to input from experts.

\subsubsection{Results Construct Validation of Model Book}

Before being used for field trials, the construct of the model book was revised according to input from experts. The results of the model book construct validation recapitulation can be seen in Table 3 .

Table 3. The Expert Validation of the Model Book Construct during the Trial

\begin{tabular}{|c|c|c|c|c|}
\hline No. & Indicator & $\begin{array}{c}\text { Percentage of } \\
\text { Validity }(\%)\end{array}$ & Information & Conclusion \\
\hline 1 & Material Planning & 86.5 & Very Valid & Very feasible \\
\hline 2 & Material Delivery Planning & 77 & Valid & feasible \\
\hline 3 & Instructor's material mastery & 86 & Very Valid & Very feasible \\
\hline 4 & $\begin{array}{l}\text { The Content of the training the } \\
\text { Material }\end{array}$ & 88 & Very Valid & Very feasible \\
\hline 5 & Purpose of the training Material & 77.5 & Valid & feasible \\
\hline
\end{tabular}


6 Systematics of the training

material

81

7 Material Evaluation

Conclusion

$85 \quad$ Very Valid

Very feasible

\begin{tabular}{llll}
\hline Conclusion & 83 & Very Valid & Very feasible \\
\hline
\end{tabular}

\subsubsection{Validation Results of the Evaluation Sheet}

The recapitulation of the validation on the evaluation sheet can be seen in tabel 4 .

Table 4. Validation Results of Evaluation Sheet

\begin{tabular}{|c|c|c|c|}
\hline No. & Indicator & Percentage & Information \\
\hline 1. & $\begin{array}{l}\text { The Planning of the Training } \\
\text { Material }\end{array}$ & 77 & Valid \\
\hline 2. & $\begin{array}{l}\text { The Content of the training the } \\
\text { Material }\end{array}$ & 79 & Valid \\
\hline 3. & Material Evaluation & 77.5 & Valid \\
\hline & Conclusion & 77.5 & Valid \\
\hline
\end{tabular}

\subsubsection{Validation Results Keterlaksanaan Sheet $P$ Training}

Validation Recapitulation of the learning feasibility can be seen in table 5 .

Table 5. Validation of Training Feasibility Sheet

\begin{tabular}{clcc}
\hline No. & \multicolumn{1}{c}{ Indicator } & Percentage & Information \\
\hline 1 & Instructor & 81.5 & Very Valid \\
2 & Training materials & 83 & Very Valid \\
3 & Training Facilities & 76 & Valid \\
4 & Training Planning & 76.5 & Valid \\
5 & Training materials & 78 & Valid \\
\hline & Conclusion & 78 & Valid \\
\hline
\end{tabular}

\subsection{Product Revisions}

Product revisions based on the results of expert validation include input models, guidebook, and learning administration. Feedback from experts who have assessed the model and the training model book in the procurement of goods / services based on the problem solving related to aspects of instructors, training materials, training facilities, and Planning was used.

\subsubsection{Design of Training Management Model of Goods / Services based on Problem Solving}


The design of the training management model for the procurement of goods / services is designed based on: (1) a description of the factual model, and (2) a needs analysis regarding the training model for the procurement of goods / services expected by the respondent.

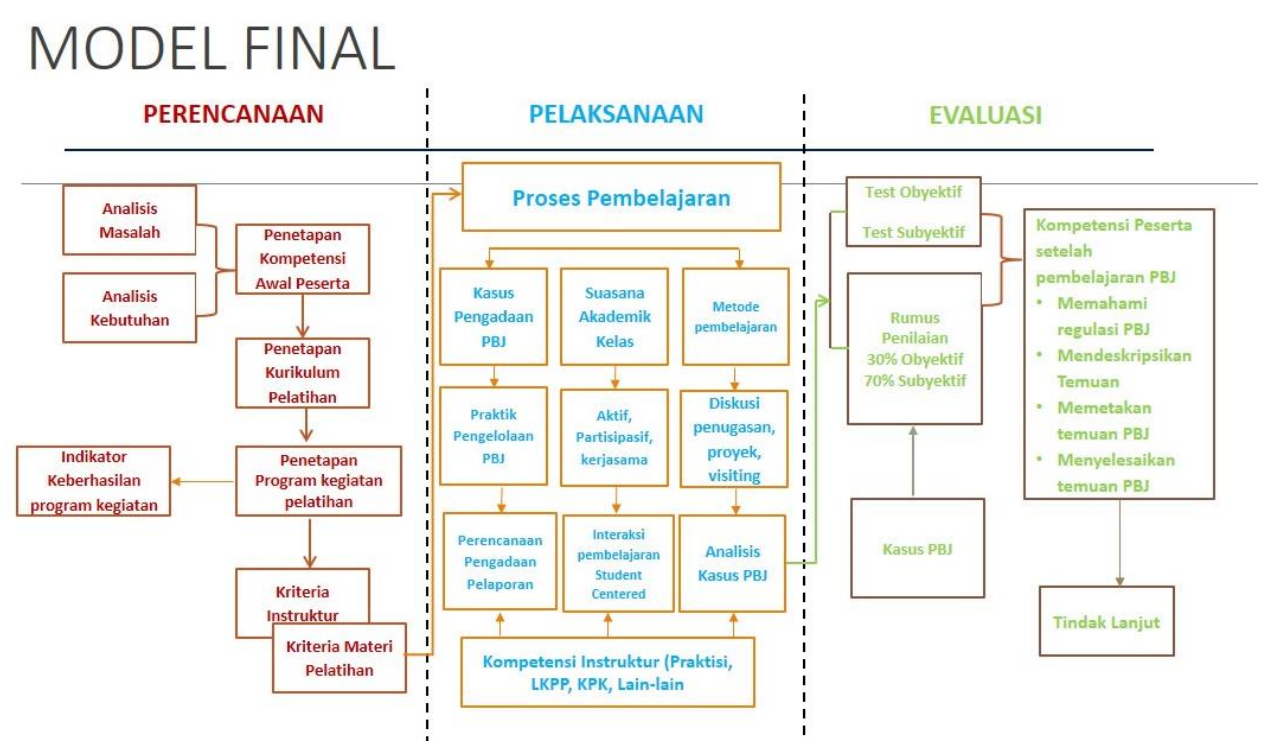

Fig 1. Design Management Model

\subsection{Training Planning}

The training planning aspect includes: (1) identification of needs; (2) training objectives, and (3) preparation of training programs and packages.

Identification of needs is required to determine the training materials relevant to the needs of training participants. The identification of training needs was carried out by analyzing the needs of the training participants for the procurement of goods / services. Each sub-division is represented by 1 participant, by analyzing the mastery of competencies, which competencies that are owned and needed. In addition, it also analyzes the training material that has been provided so far. Based on the preliminary data, a training requirement for the procurement of goods / services was designed.

Formulating training objectives is very important to direct all training activities to achieve the competencies required by the trainees. This goods / services procurement training aims to: (1) improve the competence of procurement officials; (2) provide knowledge about the concept of procurement of goods / services; (3) developing the ability to implement the procurement of goods / services.

The next stage is the preparation of a training program, which aims to provide practical guidance during the training. The content of the training program, namely; (1) program structure, training materials, and training time; (2) description of the training objectives; (3) 
description of training results and impacts; (4) training schedule; and (5) preparation of goods / services procurement training packages.

The preparation of a training package for the procurement of goods / services is a the content of the training material related to the competencies that will be provided to the training participants. Preparation of the training program of procurement of goods / services include: (1) training management guidebook, (2) instructional materials in the form of training modules (3) identification of necessary resources include: identification of those involved in the training, training facilities, tools and materials, and training room facilities .

\subsubsection{Hypothetic Model of Training Management}

After the design of the training for procurement of goods / services has been successfully compiled, the design was then consulted with experts and practitioners. Evaluation from experts as practitioners is aimed at assessing the feasibility of a training management model guidebook and training module for goods / services procurement.

Table 6. Experts and Practitioners Input to the Design of the Training Management Model

\begin{tabular}{|c|c|c|c|}
\hline No. & Assessment Aspects & Information & Input \\
\hline 1 & Model Clarity & Good & Adjust training needs \\
\hline 2 & Content accuracy & Good & \\
\hline 3 & Relevance & Sufficient & $\begin{array}{l}\text { It needs to be adapted to the } \\
\text { conditions of the participants }\end{array}$ \\
\hline 4 & Systematics Model & Good & \\
\hline 5 & Model outcome & Good & $\begin{array}{l}\text { We recommend that you add the } \\
\text { training model outcome }\end{array}$ \\
\hline
\end{tabular}

\subsection{Final Model of Training Management}

To obtain a final model of training for procurement of goods / services, a field test was conducted after the hypothetic model has been formulated. The test was done for two times: (1) limited testing, (2) field testing. In each testing, the participants were given a pretest, training material through the learning process, and a post-test. Participants were also given a questionnaire to assess the appropriateness of the training material, instructor competence, and training planning.

\subsubsection{Discussion}

Needs Assessment for the Planning of Goods / Services Procurement Training. The results of the needs analysis for the training planning for the procurement of goods / services illustrate that most of the participants really expect the training to be able to improve the competence of participants in the field of goods / services procurement to assist in the implementation of the procurement of goods / services in their respective agencies. In addition, the participants really hope that their 
limited understanding of the concept, the problems that occur in the implementation of goods / services procurement can be resolved. In general, the need for training planning is very much needed in the training of procurement of goods / services. The description above is in line with the opinion of Arthur and Bennett (200 6), Mujiman (2011: 19) that training is required to support the competence, help master the knowledge, skills and develop attitudes to project positive energy on the perspective of quality performance that will result in the loyalty to the job.

Goods / services procurement training provided to employees of government agencies, state - owned enterprise, regional government - owned enterprise and the private sector is to provide knowledge, skills and attitudes to improve competence in the field of procurement of goods/services. This is in line with the opinion of Armstrong (2009: 67) that training is a tool for human resource development that aims to help master skills and correct deficiencies in carrying out work.

\subsubsection{Goods / Services Procurement Training Planning}

The trend of the planning model for the procurement of goods / services that is expected by procurement officials. Basic Level Procurement of Goods / Services Training is a training that can provide initial provision for participants to take the Basic / First Level procurement certification exam.

\subsubsection{Planning Model of Goods / Services Procurement Training}

The results of expert validation tests on the training model provide very good value and can be used in goods / services procurement training. This means that a hypothetical model of planning the training of procurement of goods / services have met the principles in the management of training, so that the model can improve the competence of trainees, as well as allow it to be applied to the planning of training of procurement of goods / services in the place of others.

\subsection{Procurement Training Management Guidebook}

The guidebook for procurement planning training is a guide that contains the model of the training and planning training. The book of the model of planning of training the procurement of goods / services being developed entitled "The Guidelines for Planning Training Management for Goods / Services Procurement". Framework contents of this handbook include: (1) the introduction, which includes these following subtitles: background, training model and rational models; (2) the planning of training, which includes these following subtitles: training needs identification, the selection of training; (3) training preparation, which includes these following subtitles: administrative preparation and technical preparation. In general, based on the results of evaluations with education management experts, training experts, and goods / services procurement experts, it shows that the product / service procurement training guidebook is conceptually good and is suitable for use as a guide for conducting goods / services procurement training. Some 
improvements that need to be done are as follows: (1) clarity of tasks from the organizer of the training, (2) assessment of training completion, (3) the allocation of increased training time, (4) the use of the term language of a sing supplied with Indonesian be more easily understood.

\subsubsection{Goods / Services Procurement Training Module}

Based on the results of the assessment by education management experts, training experts and goods / services procurement experts, it shows that the training module product is conceptually good and suitable for use by the training participants as a module in goods / services procurement training, although there are several things that must be improved as inputs.

The developed module was stated to be feasible because it provided enormous benefits to the training participants in understanding the training material. The developed module stated: (1) providing knowledge and skills of procurement of goods / services systematically, (2) presenting case studies of procurement of goods / services and implementation of procurement of goods / services in the field, (3) fostering independent attitudes and cooperation of participants .

This is in line with Noe's opinion (20 10: 351) that training has a positive effect on the quality of trainees, both individually and socially. The same thing was stated by Beets \& Goodman (2018) which states that the training module is teaching material that is compiled in a comprehensive and systematic manner in the form of a manuscript by paying attention to these following things: (1) the module must contain complete information, (2) the module helps training participants understand the training material, learn it, and completing assignments or exam exercises required by the module itself, (3) the module content is divided into chunks according to its subtopics, (4) the modules are arranged based on an outline of the learning content and training planning with reference to the syllabus, competency standards and basic competencies

\subsubsection{Participant Assessment of Goods / Services Procurement Training Planning Model}

In planning the training management model for procurement of goods / services from limited test, the field test showed that the training management model for procurement of goods / services resulted from this development was easier for the training participants to understand and implement. Implementation of this training model provides a real experience in management training and trainees in understanding the training materials the procurement of goods / services based on the problem solving.

The description above is in line with the opinion of Gaengreco \& Carugati (20 19) which states that training is a series of activities designed to increase skills, knowledge and experience which lead to a change in attitude. The training is directed to help trainees improve their competence. This goods / services 
procurement training is also a series of activities that are well managed to help participants increase their knowledge and provide experience in procuring goods / services.

This is also in line with Syahza \& Irianti (2010) that the competence of learning outcomes is the birth of behavioral competencies, problem solving, and expression results. Goods / services procurement training which contains goods / services procurement activities will provide benefits to training participants in the form of increased competence, especially knowledge, competencies, and problem solving. According to the description of Joyce et al (2011), training has a good influence on training participants.

\subsection{The Final Results of the Development of the Planning Model for Goods / Services Procurement Training}

The discussion of the planning model for the procurement of goods / services training is inseparable from the results of the analysis of expert judgment and information on the results of research on the procurement of goods / services. Training made through stages from the draft model developed then resulted in an initial draft of the model which was then reprocessed after going through expert and practitioner validation. The results of the model were then tested, revised and then the final model was generated.

In this goods / services procurement training model, the training cycle is devoted to the implementation of training and training evaluation. The implementation of the training is aimed at adults as the target, as explained by Gibb (1983) that in adult learning, it is necessary to pay attention to several aspects: (1) learning must be shown on the main problem or the needs of the participants; (2) the experience given must be meaningful; (3) training participants must know the feedback from the training given; (4) training participants are given the freedom to share their experiences; (5) training can stimulate and increase the imagination of the facilitator or instructor in developing training materials; (6) involving training participants in achieving training objectives. Furthermore, the training evaluation is conducted to measure the success in achieving the training program objectives. Effective evaluation contains three variables, namely: material, participants and facilitators (Utomo, 2016). The evaluation carried out in this goods / service procurement training management is an evaluation of the reaction and impact of the training. This evaluation stage is carried out to determine the success of the training, with this activity it is expected that the training participants can absorb the material given. Furthermore, training program evaluation is an evaluation that is carried out to assess the overall program of activities, and the results will be used as input for further training development. In this activity what is assessed is not only the results but also the training process. Therefore, a comprehensive and objective picture of the training program is obtained. 


\subsubsection{Excellence Model Planning Training Goods / Services Procurement}

A model from results from a study must have advantages to be useful for users. The training planning model for procurement of goods / services has the following advantages:

a. It has a high value of validity, after conducting trials according to stages, and validating the model with expert tests showing a mean of 3.86. The results of the participant assessment test showed a mean value of 3.83 (measurement scale 1 to 4).

b. It has practical value in applying the model. The training management model for the procurement of goods / services because of this development is practical in its implementation both for training providers, instructors and training participants. Management functions used are planning, actuating, controlling. Planning (planning) consists of three stages, implementation ( actuating) five stages, and evaluation ( controlling) two stages.

c. Its usefulness of training management model of the procurement of goods / services is easily implemented and understood by the participants, the training management model the procurement of goods / services can improve the effectiveness of training, this fact is supported by the results of the expert evaluation with a mean value of 3.86 and a limited experiment through training on participants by showing the level of assessment of the high training model with a mean of 3.78 (measurement scale 1 to 4 ).

The implementation of the goods / services procurement training management model will provide real experience in managing the training, so that participants can increase their competence in the field of goods / services procurement which will be useful in teaching the field of goods / services procurement development. Guidelines for training management models for procurement of goods / services explain the functions of planning, implementation, and evaluation.

Guidebook for the training management model for the procurement of goods / services must be carried out by the organizers of the training activities for the procurement of goods / services so that the implementation of the training can run effectively and efficiently.

a. Model and a training package developed direct procurement officials in understanding the procurement of goods / services in depth by focusing on kegiata $\mathrm{n}$ the procurement of goods / services for the organizers of the training activities optimally organize special training.

b. Train participants to improve knowledge, skills and develop goods / services procurement

c. Problem solving based goods / service procurement models and packages can improve skills, knowledge, and abilities according to future needs. 


\subsubsection{Limitations of the Goods / Services Procurement Training Management Model}

The results of the validation test by a team of experts and limited experiments showed that the management model of training the procurement of goods / services development results have a high level of effectiveness, but the final model still has some weaknesses, including:

a. The problem solving -based goods / services procurement training management model still needs a wider examination because the population used only comes from a few goods / services procurement training.

b. Management of problem solving - based goods / services procurement training requires a large amount of money related to problem solving based assessment of training completion, facilitators, and other training support facilities.

c. The achievement of this problem-solving based goods / service management training model still requires other development and testing steps. 


\section{REFERENCES}

[1] Abdelhamid, J \& Beshara, L. (2017). Strategic use of green public procurement in the bus sector: Challenges and opportunities, Journal of Cleaner Production.

[2] Abdulaah, H \& Yusof, M. (2019). Survey data on digitalization of building procurement process by architectural firms in Abuja, Turkey. Data in Brief. 21 ,2468-2487.

[3] Ackoff, RL (1962). Scientific Method Optimizing Applied Research Decisions. New York and London: John Wiley \& Sons, Inc.

[4] Arthur, M \& Bennett, G. (2016). A review and critique of research on training and organizational-level outcomes . Journal of Human Performance . 1 , 28 - 37.

[5] Beets, K. \& Goodman, S. (2018 ). Evaluating a training program for executive

[6] coaches. Journal of Human Resource Management / SA Tydskrif vir

[7] Menslikehulpbronbestuur, 10 (3), http://dx.doi.org/10.4102/sajhrm.v10i3.425

[8] Borg, WR \& Gall, MD ( 2008 ). Educational research: An introduction (4th ed.). New York \& London: Longman.

[9] Coffman. V. \& Gray, F. (2019). Effectiveness of Training in Organizations: A MetaAnalysis of Design and Evaluation Feature. Journal of Applied Psychology.

[10] Cutcher, HK \& Ormester, JD (2019). Strategic public procurement regulatory compliance model with mediating effect of ethical behavior. Heliyon, 21 , 2468-2487.

[11]Edens, PS \& Bell, ST ( 21017 ). Effectiveness of Training in Organizations: A. MetaAnalysis of Design and Evaluation Features . Journal of Applied. Psychology, 88 (2), 234 245.

[12]Fuad, Z. \& Alhamidy, U. (2017). e-Procurement Universiti Kebangsaan Malaysia a. Journal of Procurement, 18 (3), 29-35.

[13] Gardenal, F. (2013). A model to measure e-procurement impacts on organizational performance. Journal of Public Procurement, 13 (2), 215-242.

[14] Goldblatt, M. \& Wood, C. (2018). Managerial training effectiveness A meta analysis. Journal of Personal Review.

[15] Giangreco, A., Carugati, A., Sebastiano, A. \& Bella, DD (2019). Trainees reactions to training: shaping groups and courses for happier trainees. Journal The International Journal of Human Resource Management, 21 , 2468-2487.

[16] Guazzini, V. \& Duradoni, B. (2020). Impact of Frame-of-Reference and Behavioral Observation Training on Alternative Training Effectiveness Criteria. Journal of Human Performance.

[17] Gulo, W. (2002). Teaching and Learning Strategy. Jakarta: Gramedia Widiasarana.

[18] Habibi \& Untari, D. (2018). 2016-2017 Goods / Services Procurement Anomaly . Undip Manabis Journal

[19] Hopkins, D. (1993). A Teacher's Guide to Classroom Research. Philadelphia: Open University Press.

[20] Ilahiyyah EN, Pujotomo D., (2018) Performance Measurement of Goods / Services Procurement Using the Indonesian Procurement Maturity Model in the Procurement Service Unit of Diponegoro University, Jurnal Ekonomika, 7 (4) 13-21 
[21] Jean, P., Rusdarti, \& Sucihatiningsih. DWP (2017). Vocational Training Model Based on Utilization of Bamboo Shoots in the Paloan Village Community, Sengah Temila District, Landak Regency. Journal of Vocational and Career Educational, 2 (1), 70-78.

[22] John JO I. Ihalaw. (2005). Building Theory: Third Edition of the Millennium. Salatiga: Satya Wacana University Press.

[23] Jonassen, K \& Hung, AB (2018). Small business value chains in local government authorities (LGAs) procurement contracts in Tanzania. Cogent Business \& Management . 17, 251-273.

[24] Joyce, B., Weil, M. \& Calhoun, E. (2011). Models Of Teaching Model - Models Learning. Yogyakarta: Student Library.

[25] Justis, KL \& Kedia, J. (2017). Spanish Public Procurement: legislation, open data source and extracting valuable information of procurement announcements . Procedia Computer Science.

[26] Kirkpatrick, DL (2006). Seven keys to unlock the four levels of evaluation. Journal of Performance Improvement, 45 (7).

[27] Kirkpatrick, D. \& Kirkpatrick, J. (2006). Evaluating training programs: The four levels. Berrett-Koehler Publishers.

[28] Kristiadi. (2018). Analysis and Design of Information Systems for Procurement of Goods and Services for the Direct Procurement Method at the Jambi Provincial Education Office. Journal of Information Systems Management.

[29] Ladina, Andritia. (2019). The Effect of Training and Trainer Competence on Employee Performance of PT. PLN (Persero) Rayon Manahan , UMS Journal

[30]Lin, YT, Chen, S., \& Chuang, H. (2019). The Effect of Organizational Commitment on Employee Reactions to Educational Training: An Evaluation Using the Kirkpatrick FourLevel Model. International Journal of Management, 28 (3), 926-938.

[31] Lestyowati, J. Problem Analysis of E-purchasing in Procurement of Goods and Service Unit Work (Case Study of the Ministry of Finance Satker). National Symposium on State Finance, 1 (1), 669-695.

[32] Mathis , R. L ., And Jackson , J. H . ( 2002 ) . Human resource management . Jakarta: Four Salemba.

[33] McLaren. \& Gog, J. (2018). Temporalities in evaluation of training course. Work 41 Journal.

[34] Moreau, C. \& Engeset, J. (2019). Rethinking health sector procurement as developmental linkages in East Africa. Social Science \& Medicine.

[35] Mujiman, H. (2011). Self-learning based training management . Yogyakarta: Offset Student Library.

[36] Nadler. J. (1863). Effectiviness Training. NY: McGraw-Hill.

[37] Noonan, Sulsky (2019) Impact of Frame of Reference and Behavioral Observation Training on Alternative Training Effectiveness Criteria in a Canadian Military Sample, The Journal of Human Performance, 17 (1), pp. 1-30.

[38] Noe, RA (2010). Human resource management achieves excellence compete. NY: McGraw-Hill. 
[39] Nurmandi A., Kim S., (2019). Making e procurement work in a decentralized procurement system . International Journal of Public Sector Management Vol. 28 No. 3, 2015 pp. 198220 Emerald Group Publishing Limited 0951-3558 DOI 10.1108 / IJPSM-03-2019-0035.

[40] Nguyen, K \& Nguyen, J. (2018). The NISPI framework: Analyzing collaborative problemsolving from students' physical interactions . Elsevier Editorial System for Computers \& Education.

[41] Ozsoy, M. \& Ataman, J. (2019). Measuring cognitive load with subjective rating scales during problem solving: differences between immediate and delayed ratings. Journal of Marketing Research.

[42] Okibo, W., Matunga, DA, \& Nyanamba, SO (2013). The Effect of E Procurement Practices on Effective Procurement in Public Hospitals: A Case of KISII Level 5 Hospital. American International Journal of Contemporary Research, 3 (8), 103 - 111.

[43] Powell, KS, Yalcin Serkan. (2018). Managerial Training Effectiveness. Vol. 39 No. 2, 2018 pp. 227-241 q Emerald Group Publishing Limited 0048-3486 DOI 10.1108 / 00483481011017435

[44] Prasojo, DL \& Habibi, A. (2020). Data relating to factors affecting teachers' burnout: A sem analysis in an Asian context. Data in Brief.

[45] Ronald, D. \& Omwenga, T. (2016). The Effect of Organizational Commitment on Employee Reactions to Educational Training: An Evaluation using the Kirkpatrick Four-level Model. International Journal of Management.

[46] Sastamoinen, J., Reijonen, H. \& Tammi, T. (2017), The role of training in dismantling barriers to sme participation in public procurement, Journal of Public Procurement, 17 (1), pp. 1-30.

[47] Santos, M., Teresa, M., \& Monteiro, A. (2012). Temporalities in evaluation of training courses: Standards and restrictions practiced by Human Resources professionals. Ergonomic Analysis on Work Activity and Training, 41 (2), pp. 217-226.

[48] Selvarajah, C., Tammy, SL, \& Robert, JT, (2000). Management Training and Development: A New Zealand Study. Journal of Management \& Organization , 28-41.

[49] Sugiyono. (201 8 ). Quantitative Research Methods, Qualitative and $R \& D$. Bandung: Alfabeta.

[50] Supriyanto, A \& Zauhar S (2019). Analysis of the Effectiveness of the E-Procurement System in Government Goods / Services Procurement (Study at the Faculty of Administrative Sciences, Brawijaya University ) . Journal of IAP UB

[51] Taufik \& Darmais (2017). The Effect of E-Procurement Implementation and the Competence of Commitment Making Officials on the Implementation of Goods and Services Procurement and Its Implications for Capital Expenditure Absorption (Study in the Work Unit of the Payment Scope of the Banda Aceh State Treasury Service Office ), Jurnal Accountansindo

[52] Temaluru, M. \& Falah, A. (2017). Implementation of the Procurement Service Unit (ULP) on the Efficiency and Effectiveness of the Procurement of Goods / Services . Journal of Finance \& Business, 8 (1) 29-35 
[53] Thang, N. \& Tho, N. (2010). Determinants of learning performance of business students in a transitional market. Quality Assurance in Education, 18 (4), 304-316.

[54] Tharenou, AP, Saks, AM, \& Moore, C. (20 19). A review and critique of research on training and organizational-level outcomes. Human Resources Management Review, 17, 251-273.

[55] Tika, B \& Mele, G. (2019). The Effect of the Implementation of the Procurement Service Unit (ULP) on the Efficiency and Effectiveness of the Procurement of Goods / Services in the Government of Papua Province. Journal of Regional Economic and Financial Studies, 16 (4) 67-76.

[56] Tracey, B., Duraisamy, K. \& Alonso, JJ (2017). A Machine Learning Strategy to Assist Turbulence Model Development. University of Michigan Duderstadt Center on December 14 American Institute of Aeronautics and Astronautics, 1-22.

[57] Ueki, Y. \& Martínez, JMG (201 8 ). The impact of engineers' skills and problem solving abilities on process innovation. Journal of Economic Research Ekonomska Istraživanja Latest Articles.

[58] Utomo , AB , Widodo , J., Supartono, \& Haryono. (2016) . The development of training management model of soft Skill learning integrated with chemo entrepreneurship (cep) for high school chemistry teachers in semarang. 